\title{
Challenges in Managing Natural Resources: A Short Review of Economic Instruments
}

\section{Silvia F* \\ Department of Political and International Sciences, University of Siena, Italy}

*Corresponding author: Silvia Ferrini, Department of Political and International Sciences, University of Siena, ZICER Building 1.13, Italy, Tel: (+39) (0577) 233343, Email: S.Ferrini@uea.ac.uk

\section{Review Article \\ Volume 2 Issue 1}

Received Date: January 13, 2018

Published Date: February 16, 2018

DOI: $10.23880 /$ jenr-16000119

\section{Abstract}

As planetary boundaries impose a wider sustainable management of natural resources within private and public sectors, scientists, economists and practitioners are challenged to cooperate to promote newer strategies for natural resources. The framework of Ecosystem Services is paving a new way to bridge cross-discipline research. This short article reviews the Ecosystem Services classification and suggests economic methods and approaches that could play an important role in improving the management of natural resources. The review presents economic methods and approaches which can support broadening the application of Ecosystem Services framework and cross-discipline collaboration.

Keywords: Ecosystem Services; Natural resources; Planetary boundaries

Abbreviations: NR: Natural Resources; Circular Economy (CE), PES: Payment for Ecosystem services; NCA: Natural Capital Accounting; CSR: Corporate Social Responsibility; GPP: Green Public Procurement; ESs: Ecosystem services; IPBES: International Platform on Biodiversity and Ecosystem Services.

\section{Introduction}

The interaction of humans and natural resources is well established; humans need natural resources (NR) for survival and development and natural resources have been tamed and shaped by humans for humans. For many centuries the pressure on natural resources happened to be within sustainable limits and human development progressed by and large smoothly. When a resource was exhausted (e.g. land fertility) humans could move or use an alternative resource e.g. nomadism - development had no planet boundaries. Nowadays, it is clear that planetary boundaries constraint natural resource management [1].
These boundaries challenge practitioners and researchers of different disciplines to cooperate and understand natural resources and promote sustainable development pathways. This short article aims at revising economic methods and approaches that can bridge disciplines and promote sustainable development.

\section{Economic Instruments for Natural Resources}

A cross discipline dialogue is an essential component of sustainable management of natural resources and the Millenium Ecosystem Assessment (MA, 2005) provided a novel classification of natural resources to promote collaborative management and a shared and flexible framework for supporting the inclusion of ecosystem goods and services into decision-making. This classification has influenced the current dialogue on natural resources and environmental management and promotes international cross-disciplinary collaborations 


\section{Journal of Ecology \& Natural Resources}

[2]. The International Platform on Biodiversity and Ecosystem Services (IPBES) is an example [3]. Figure 1 summarize an example of Ecosystem Services classification and main dependent sectors. The stock of natural resources presents unique, and still partially understood, functioning processes and provides benefits to private and public sectors through Ecosystem services (ESs). Human beings receive benefits and values from the complementary work of ESs and inputs from private and public institutions [4].
Human welfare depends on natural resources and ESs is a classification which promotes the dialogue and cooperation of science, social science and policy-makers. The MA classification needs further refinement to fit the needs of environmental valuation and in particular there is a request to clearly distinguish intermediate and final ecosystem services [5-7]. Only the latter can be given a monetary valuation [8]. Governments before private institutions recognize the dependency of human on ESs and different initiatives have been launched in the past 15 years (e.g. MA 2005, TEEB, 2013) but the management of natural resources is still challenging [9].

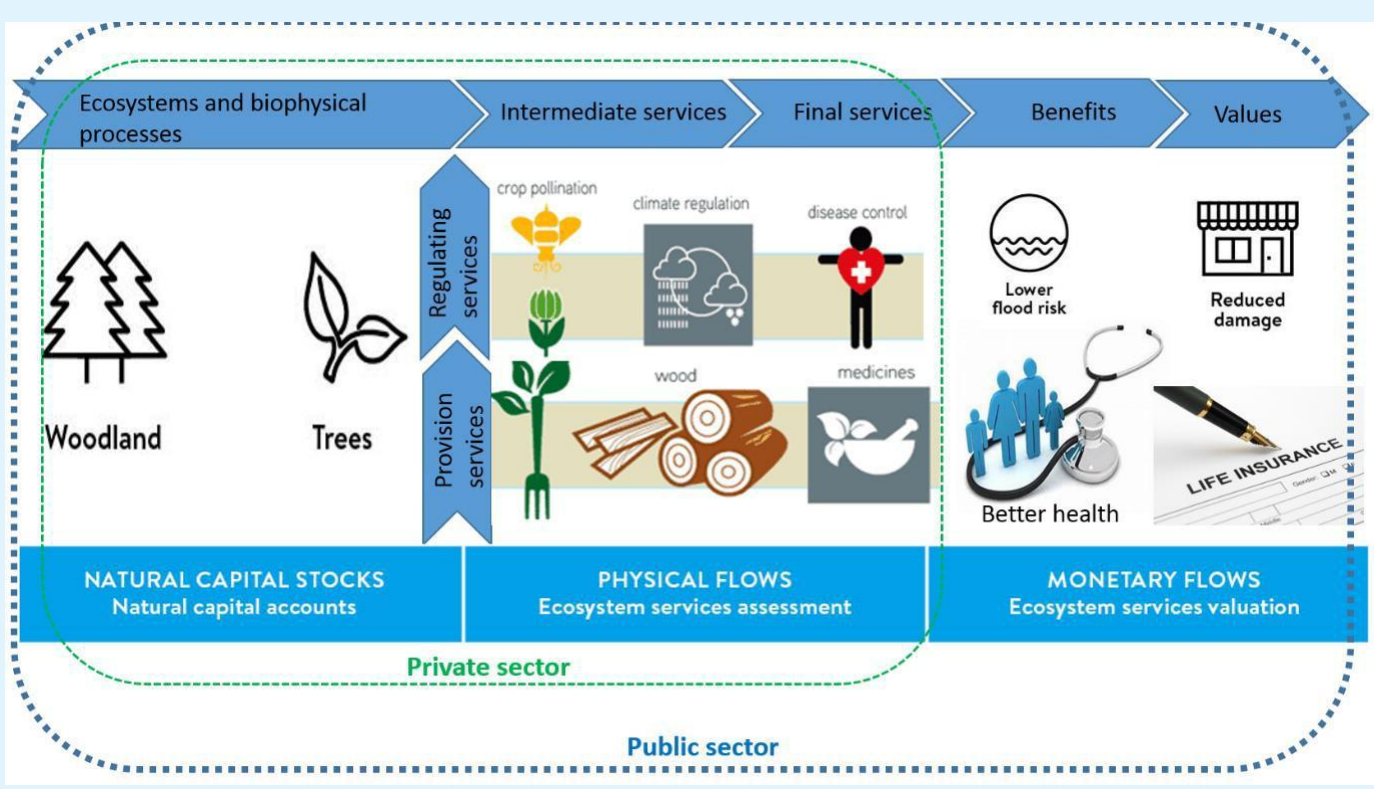

Figure 1: Classification of ESs and dependency of private and public institutions. Source: Modified from https://www.raconteur.net/sponsored/success-water-industrymuch-financial-capital and UNESCO.

Note: the picture consider supporting services as a component of regulation services.

The sustainable management of natural resources requires a better understanding of ecosystem functioning and standardized methods for measuring, quantifying and communicating ESs qualities and dependency [10]. Economists have contributes to this dialogue supporting the application of different methods for private and public institutions.

The main methods, which could play a significant role in the next decade for improving sustainable management of natural resources, are:

Green Public Procurement (GPP): Governments set preference criteria on procurement to promote environmental friendly goods and services; this should lead to spillover effects on responsible management of NR. Cheng, et al. provides a comprehensive review of GPP [11]. Currently, the ESs framework is completely overlooked in the green public procurement nomenclature but it is likely that this is changing in the future. Cheng et al (2018) conclude that "GPP will become of more relevance in the next years" and more research is needed to bring the ESs agenda into the GPP.

Corporate Social Responsibility (CSR): Corporates are investing growing attention on measuring and managing their impact on nature and society and we expect that ESs might get a prominent role in the future 
[12]. For years Sustainable labelling (e.g. FSC for wood derived products) has assisted corporates in promoting and merchandising their responsible NR management. Nowadays, the Natural Capital Coalition protocol is the framework defined by private and public institutions to understand and manage their dependency on nature and ESs are the approach suggested for encouraging NR management. D'amato, et al. present a first attempt of incorporating ESs in CSR of forestry sector [13]. They observe that "despite the increasing awareness of corporate dependencies and impacts on ecosystems and related business risks and opportunities, scientific and corporate-based information on these issues is lacking". It is likely that CSR will play a role in improving NR management.

Natural Capital Accounting (NCA): World Bank and United Nations Environmental Program (SEEA, 2012; SEEA-EEA 2012, UNEP 2014) have recently prompted the attention on the necessity to incorporate broader effects of NR management into national macro-economic indicators (e.g. Gross Domestic Product) [14-17]. European Union, UK government and other governments are testing experimental natural capital accounting strategies (e.g. EU Biodiversity Strategy 2012, UK-NEA 2014) and this is going to be a growing research area [18].

Payment for Ecosystem Services (PES): this is a new market-based policy instrument which facilitates the negotiation of ESs between providers and beneficiaries. The provider of ESs (e.g. farmer who facilitates the nesting of pollinators) gets paid by beneficiaries (e.g. owners of apple orchards) for the service provided. While the positive effect of responsible management of NR is rarely captured by market transaction the PES aims at creating new markets where these benefits are acknowledge and traded. Jespersen \& Gallemore conduct an extensive review of PES and conclude that the implementation of PES requires extensive knowledge on how to create and maintain effective institutions. Institutions are also crucial in managing ESs through Common Asset Trusts [19,20]. New instruments for managing ESs will support sustainable management of NR.

Integrated modelling is a parallel tool which aims at capturing the complexity of ESs and human behaviours and can potentially include economic, scientific and social methods to understand and forecast issues with NR management. Finally two overarching frameworks which can support the management of natural resources are:
Circular Economy (CE): The CE is an old approach given a new fashionable status and is now dominating the decision makers' discourses [21]. The EU Action Plan, approved in 2015 by the EU commission, sets the strategies to move from a linear to a circular economy and China is using the circular economy as a strategic framework to preserve environmental resources and competitiveness [22-24]. The Ellen MacArthur Foundation reports that the circular economy is 'a continuous positive development cycle that preserves and enhances natural capital, optimises resource yields, and minimises system risks by managing finite stocks and renewable flows' [25].

Balance Sheet Approach' (UK-NEAFO 2014, Turner 2016). This is both a process and a tool which provides a novel way of collating, analysing and presenting evidence and data within the overall policy process. It is a different way for analysts to build up, interrogate and present evidence to stakeholders and decision makers and is designed to be more deliberative and inclusive, in the light of the inevitable trade-offs that beset efforts to promote social progress [26,27].

\section{Conclusions}

The paper contributes to review areas of future interest and research for sustainable management of natural resources. A set of economic methods and approaches is reviewed and extensive research on sustainable management of natural resources is encouraged. Ecosystem Services framework could facilitate the cross discipline collaboration and broaden the understanding of nature dependency of private and public sector.

\section{References}

1. RockstrÖm J, Will S, Kevin N, Persson A, Stuart FC, et al. (2009) A safe operating space for humanity. Nature 461: 472-475.

2. De Groot RS, Alkemade R, Braat L, Hein L, Willemen L (2010) Challenges in integrating the concept of ecosystem services and values in landscape planning, management and decision making. Eco Comp 7(3): 260-272.

3. IPBES (2016) The assessment report of the Intergovernmental Science-Policy Platform on Biodiversity and Ecosystem Services on pollinators, pollination and food production. 
4. Guo Z, Xiao X, Li D (2000) An assessment of ecosystem services: water flow regulation and hydroelectric power production. Ecol Appl 10(3): 925-936.

5. Fisher B, Turner RK (2008) Ecosystem services: classification for valuation. Bio Cons 141(5): 11671169.

6. Fisher B, Turner KR, Morling P (2009) Defining and classifying ecosystem services for decision making. Ecol Econ 68(3): 643-653.

7. Fisher B, Turner RK (2008) Ecosystem services: Classification for valuation. Biological Conservation 141(5): 1167-1169.

8. Boyd J, Banzhaf S (2007) What are ecosystem services? The need for standardized environmental accounting units. Ecol Econ 63 (2-3): 616-626.

9. TEEB (2013) The economics of ecosystems and biodiversity: guidance manual for TEEB country studies.

10. Sarkki S (2017) Governance services: Co-producing human well-being with ecosystem services. Ecosyst Serv 27: 82-91.

11. Cheng W, Appolloni A, D'Amato A, Zhu Q (2018) Green Public Procurement, missing concepts and future trends - A critical review. J Clean Prod 176: 770-784.

12. GRI-Global Reporting Initiative (2017) G4 Sustainability Reporting Guidelines, Reporting Principles and Standard Disclosure.

13. D’amato D, Li N, Rekola M, Toppinen A, Lu FF (2015) Linking forest ecosystem services to corporate sustainability disclosure: A conceptual analysis. Ecosyst Serv 14: 170-178.

14. World Bank (2011) 'The Changing Wealth of Nations', Washington DC: World Bank.

15. United Nations, European Commission, Food and Agricultural Organization of the United Nations, International Monetary Fund, Organisation for Economic Co-operation and Development, The World Bank (2014a) System of Environmental-Economic Accounting (SEEA) 2012 - Central Framework. United Nations, New York.
16. United Nations, European Commission, Food and Agricultural Organization of the United Nations, Organisation for Economic Co-operation and Development, The World Bank (2014b) System of Environmental-Economic Accounting 2012 Experimental Ecosystem Accounting (SEEA-EEA). United Nations, New York.

17. UNEP and UNU-IHDP (2014) Inclusive Wealth Report 2014. Measuring progress toward sustainability. Cambridge: Cambridge University Press.

18. EP (2012) European Parliament resolution of 20 April 2012 on our life insurance, our natural capital: an EU biodiversity strategy to 2020 (2011/2307(INI)).

19. Jespersen K, Gallemore C (2018) The Institutional Work of Payments for Ecosystem Services: Why the Mundane Should Matter. Eco Eco 146: 507-519.

20. Costanza R, de Groot R, Braat L, Kubiszewski I, Fioramonti L, et al. (2017) Twenty years of ecosystem services: How far have we come and how far do we still need to go? Ecosyst Serv 28: 1-16.

21. Pearce D, Turner RK (1990) Economics of natural resources and the environment.

22. European Commission (2015) Closing the Loop e an EU Action Plan for the Circular Economy. Communication from the Commission to the European Parliament, the Council, the European Economic and Social Committee and the Committee of the Regions, COM (2015) 0614, Brussels.

23. European Environment Agency (2016) Circular Economy in Europe: Developing the Knowledge Base.

24. Geng Y, Sarkis J, Ulgiati S, Zhang P (2013) Measuring China's Circular Economy. Science 339(6127): 15261527.

25. Ellen MacArthur Foundation (2015) Circular Economy Overview.

26. Turner RK (2016) The Balance Sheet approach. In Potschin, et al. (Ed), Routledge Handbook of Ecosystem Services, Routledge, London.

27. UK National Ecosystem Assessment (2014) The UK National Ecosystem Assessment: Follow-on-UKNEAFO. UNEP-WCMC, LWEC, UK. 